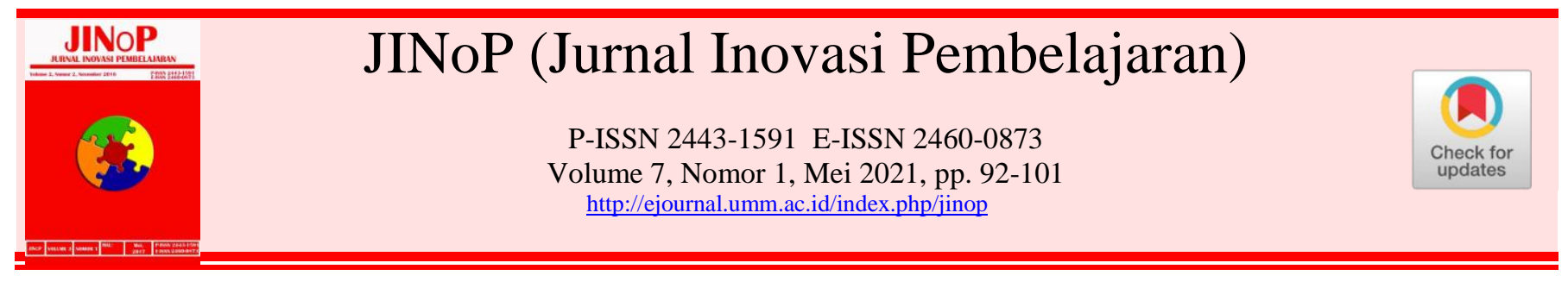

\title{
The Implementation of Higher Order Thinking Skills (HOTS) trough Lesson Study: A Case Study at Islamic School in Thailand
}

\author{
Masyhud $^{1)^{*}}$, Laela Himah Nurbatra ${ }^{2)}$, Sri Hartiningsih ${ }^{3)}$ \\ ${ }^{1}$ English Language Education Department, Faculty of Teaching and Training Education, Universitas \\ Muhammadiyah Malang, J1. Raya Tlogomas, No. 246, Malang City, Indonesia \\ ${ }^{2}$ English Language Education Department, Faculty of Teaching and Training Education, Universitas \\ Muhammadiyah Malang, J1. Raya Tlogomas, No. 246, Malang City, Indonesia \\ ${ }^{3}$ English Language Education Department, Faculty of Teaching and Training Education, Universitas \\ Muhammadiyah Malang, Jl. Raya Tlogomas, No. 246, Malang City, Indonesia
}

masyhud863@umm.ac.id*; nurbatra@umm.ac.id, hartiningsih@umm.ac.id

*Penulis Koresponden

\begin{abstract}
ABSTRAK
Di era milenial ini, Higher Order Thinking Skills (HOTS) dianggap sebagai tema penting dalam dunia pendidikan. Tema tersebut muncul dalam semua kegiatan pembelajaran karena memungkinkan siswa untuk menggunakan pemikiran kritis dalam pemecahan masalah mereka. HOTS tidak lepas dari Bloom Taksonomi. HOTS penting untuk diintegrasikan di kelas-kelas di lingkungan sekolah yang beragam. Oleh karena itu, tujuan dari penelitian ini adalah menggambarkan implementasi HOTS melalui Lesson Study. Penelitian dilakukan di salah satu Pesantren di Thailand Selatan. Pesantren merupakan Pondok Pesantren yang mengintegrasikan nilai-nilai Islam dalam proses belajar mengajarnya. Berdasarkan wawancara awal dengan pengelola sekolah, siswa berasal dari latar belakang ekonomi yang berbeda. Akibatnya, mereka memiliki tingkat kompetensi kognitif dan linguistik yang berbeda. Selain itu, penelitian ini menggunakan pendekatan kualitatif untuk mendeskripsikan penerapan HOTS melalui Lesson Study. Untuk memperoleh data yang memadai digunakan observasi partisipatif, Focused group discussion (FGD) dan analisis dokumen digunakan sebagai instrumen penelitian. Hasil penelitian menunjukkan bahwa HOTS di sekolah ini dalam beberapa kegiatan seperti permainan, diskusi kelompok dan permainan peran. Ini dapat membimbing siswa untuk mengembangkan kemampuan bahasa Inggris mereka.

Kata Kunci: Higer Order Thinking Skills; Lesson Study; Pondok Pesantren
\end{abstract}

\section{ABSTRACT}

In this millennial era, Higher Order Thinking Skills (HOTS) is regarded as an important theme in education. The theme has emerged in all learning activities as it enables students to use critical thinking in their problem-solving. HOTS cannot be separated from Bloom's Taxonomy. HOTS is important to be integrated with classes in diverse school settings. Therefore, the aim of this research is to draw the implementation of HOTS through Lesson Study. The research was conducted in one of the Islamic schools in south Thailand. The school is an Islamic Boarding School that integrates Islamic values in its learning and teaching process. Based on a preliminary interview with the school administrator, the students are coming from different economical backgrounds. As the consequence, they have a different level of cognitive and linguistic competence. Moreover, the present research was utilized a qualitative approach to describe the implementation of HOTS through Lesson Study. To acquire adequate data, participatory observation, Focused group discussion (FGD), and document analysis were used as the research instrument. The result shows that HOTS in 
this school in several activities such as game competitions, group discussion, and roleplay. It can guide students to expose their English skills.

Keywords: Hihger Order Thinking Skills; Lesson Study; Islamic School

diunggah: 2019-11-23, direvisi: 2021-05-11, diterima: 2021-05-22, dipublikasi: 2021-05-24

Copyright (c) 2021 Masyhud et al

This is an open access article under the CC-BY license

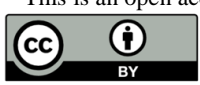

Cara sitasi: Masyhud, M., Nurbatra, L. H., \& Hartiningsih, S. (2021). The Implementation of Higher Order Thinking Skills (HOTS) trough Lesson Study: A Case Study at Islamic School in Thailand. JINoP (Jurnal Inovasi Pembelajaran), 7(1), 92-101. https://doi.org/10.22219/jinop.v7i1.10357

\section{INTRODUCTION}

In this millennial era, Higher Order Thinking Skills (HOTS) is regarded as an important element in education (Setyarini, Muslim, Rukmini, Yuliasri, \& Mujianto, 2018). The theme has emerged in all learning activities as it enables students to use critical thinking in their problem solving. In accordance to that, the teachers are demanded to integrate HOTS in their classroom activities. HOTS cannot be separated from Bloom's Taxonomy. The Bloom's Taxonomy (1984) is developed in 1956 with six objectives such as knowledge, comprehension, application, analysis, synthesis, and evaluation. The objectives were then is classified into Low Order Thinking Skills (LOTS) and Higher Order Thinking Skills (HOTS). The objectives stated in the Bloom's Taxonomy can be widely used in the identifiable and operational words for students' achievement. Although the Bloom's Taxonomy was then revised to insert 'creation' which is more complicated than evaluation; the classification of HOTS and LOTS in Bloom's Taxonomy can still be utilized. HOTS therefore, is defined as complex skills that combine logical analytical reasoning, reflective thinking, creative thinking and evaluative thinking to solve the students' particular problems (Nguyễn \& Nguyễn, 2017). HOTS is therefore is important to be integrated in classes in diverse school setting which have different culture and background of students.

The setting of the research is in one of Islamic schools in Phang-nga at South Thailand. The school is an Islamic Boarding School which integrates Islamic values in their learning and teaching process. In addition, the school also accommodates students for junior and high school level from their neighborhood people.

Based on preliminary interview with the school administrator, the students are coming from different economical background. As the consequence, they have different level of cognitive and linguistic competence. The school teacher also mentioned that they have three problems in English teaching, namely low level of students' motivation, low level of critical thinking and the teacher's inadequate knowledge and skills in how to integrate Higher Order Thinking Skills in their classrooms. As the first problem, low students' motivation plays important role in shaping the students' attitudes in their English learning. The English teacher mentioned that the students do not have good motivation to learn English because they think that they do not use the language in their real life. Secondly, students at Tarbiyah Islamiyah School Thailand also face difficulties in critical thinking as they have limited resources that integrate critical thinking in the class. Lastly, the teacher stated that he had difficulties to integrate HOTS activitiy because he did not have adequate knowledge and skills to do so.

Although the teachers do not have adequate knowledge and skills in integrating HOTS in their classroom, the school indeed owns facility that supports the 
implementation of such as library and smart room. The library offers various types of readings for the students that the students can visit anytime during the school time. Moreover, the school also provides smart room which is equipped with projectors, computers, loudspeakers and internet connection so that they can use Information and Communication Technology (ICT) in the learning process. As there is only one smart room for the whole school, the English teacher cannot use smart room in every lesson. He needs to plan in advance to book the room which is also used by different subjects. In addition, even though the internet connection is provided, the students at the school are not allowed to use their smart phone in the school.

The mentioned school's background is interesting to implement Higher Order Thinking Skills (HOTS) because HOTS can be integrated in students' learning activities such as observation, explanation, comparison, and prediction (Putra, 2018). In regards to that, the learning activities that integrate HOTS can be implemented both in individual or group activities. Individual understanding and reasoning skill can be addressed in individual task in the classroom (Mumu \& Tanujaya, 2019). Additionally, the student's skill in problem solving can also developed in individual or group work. The team work enables the group of students to cooperatively and collaboratively identify problems and suggest the appropriate solution for that. In doing so, Anderson, Howe, Anderson, Howe, Soden, Halliday, \& Low (2001) advocated peer critiques that include direct instruction, demonstration and mentorship.

Kong (2015) devided HOTS into five domains namely skills to relate the students' knowledge with their problems, analyze the problems, logically conclude the problems, argue the problems and solve the problems. The first domain indicates the skills to make connection of what the students previously learnt and what they are currently learning with the real context in their life. This means that the students are not only remembering or understanding the knowledge, but also connecting that into their environment. The second domain highlights the critical thinking which is carefully consider and analyze things. Teachers need to encourage and direct the students to improve their curiosity and critical thinking for learning new things. Lastly, the third domain focuses on how the students can solve problems using their Higher Order Thinking Skills. This means that the students were given opportunities to identify problems and solve them using analytical and evaluative perspective.

To develop the students Higher Order Thinking Skill is not an easy task for teachers. A study found out that teacher does not have adequate training to integrate HOTS in their lessons (Mahanal, Zubaidah, Bahri, \& Dinnurriya, 2016). They further contended that the teachers' guide is essential to make the thinking skills visible and relevant for the students' context. This claim emphasizes that the teachers' perception, attitudes, knowledge and skills play significant role in the integration of HOTS in classroom activities. Therefore, the implemention of HOTS through Lesson Study is rarely discussed.

Lesson study was firstly hosted by Japan more than a century ago (Vermunt, Vrikki, van Halem, Warwick, \& Mercer, 2019). Then, it has been developed largely in Europe more than decades (Dudley, 2013). Moreover, in Indoensia its has been introduced in Indonesia over two decades (Wahono, Perdana, Study, \& Pemula, 2013). rapid spread of LS in various countries indicates that LS can be accepted in educational environment and is considered capable of contributing to the development of education, especially for students. Haryoto \& Narimo (2013) indicate that LS can contribute to students's critical thinking to solve a problem, and it can enhance the students's teamwork. 
The aim of LS is to develop teachers's teaching collaboratively. It is believed to improve teacher's competeces in some parts; deciding enhancement aims, constructing hypotheses and goals, providing collaborative teaching research, and assesing the teaching process (Vrikki, Warwick, Vermunt, Mercer, \& Van Halem, 2017). The fundamental principle in LS is the learning process controlloled, monitored and evaluated together with the other teachers. Moreover, Masyhud (2018) stated that LS can also give impact on the classroom interaction. It can assist the student with dynamic classroom interaction.

Based on the above arguments, the current research addresses the integration of Higher Order Thinking Skilss (HOTS) and Lesson Study in English teaching in two different countries, Thailand and Indonesia. It is interesting motion because it is rarely highlighted by other same researchs. In doing so, this research expects the result can show the implementation Lesson Study among different countries can be conducted and eliminated the barriers in teaching development.

\section{METHODS}

Qualitative approach was utilized in this research. The intrsuments are particapatory observation, FGD, and Document analysis. Morover, Thi reserach is part of community program collaborated between Indonesian University and secondary school at Thailand. The program was operated for six months including the preparation, immplemantaion and reflection. The stages are elaborated below

\section{Planning stage}

The planning stage covered the discussion with the headmaster of the school in order to get enough information of learning English process at that school. The discussion also provided the information of the total number of English teachers and students at that school. This information will lead LS team to the background of Lesson Study. In addition, the headmaster can recommend the English teachers particapted in the Lesson Study. The next is formulating the LS team. The team will be involved three lectures of English Language Education of UMM and two English teachers. The LS team worked together to identify the problems in teaching and learning English. The last team managed Lesson Study and HOTS workshop for all teachers. It was aimed to assist deep understanding to all teachers about LS and HOTS. It was needed due to limited knowledge of LS and HOTS for the teachers. The workshop was held for one day. The workshop provided explanation about history, purpose, the steps of implementing LS and coaching clinic how to implement HOTS in the class through LS.

\section{Implementation satge}

The implementation of present Lesson Study will be conducted into two cycles. Each cycle will involve three phases; Plan-Do-See. The stages are displayed below. Plan covers:

a. LS team collaborates to formulate the lesson design including the learning media such as the lesson plan, the materials and documentary tools.

b. LS team decides the model teacher who will implement the lesson design. Other teachers will be set as moderator, observer, note-taker and documentation.

c. LS team will set the goals of program.

d. LS team will discuss together the lesson plan.

e. LS team will revise the learning media based on the discussion input

f. LS team will prepare the media for $D o$ phase. 
Do covers:

a. The LS team will implement lesson plan.

b. The LS team will set the class based on the agreement in Plan phase. The students are expected to learn in accordance with the team's goals.

c. The Observers will observe every single moment happened in the leraning process to find valuable input for the next cycle.

d. The Observers will observe the learning rigidly. They will write or record interesting moment in the learning process.

See covers:

a. The LS team will evaluate the leraning process through massive collaborative discussion. Each member will give suggestion for the learning process.

b. The Observers will deliver the strenghts and the weaknesses of the learning process by providing the proof.

c. The strengths will be best practices for the next cycles.

d. The LS team will continue for the next cycles based on the reflection result.

\section{FINDINGS AND DISCUSSION}

The findings cover the process of the implementation of Lesson study to improve the student's High Order Thinking Skill (HOTS) at Tarbiah Islamiah School Thailand. In general, the impelementation of LS divides into two parts; Planning for the implementation of Lesson Study and the implementation of Lesson Study. The details are elaborated as follows.

\section{Planning for the implementation of Lesson Study}

Pre-Lesson Study concerns on the preparation before the implementation of LS. It is needed to make sure the program can be organized along the process of LS. It included the process of obtaining allowance from Headmaster, deciding the teacher who will involve in LS, and in what grade LS will be applied?

LS Team contacted the headmaster and English teacher to arrange the LS implementation schedule. We decided to have schedule at 8-11 July. Moreover, the headmaster recommended 1 English teacher who would be participated in this program. He also invited all tecahres to join workshop on Lesson Study and HOTS. Morover, LS Team communicated with the headmaster and English teacher through social media; email and whatsap. We planed the program by the social media including the planning for the learning process. Furthermore, we agreed to have two cycles and XII grade as the subject. Every cycle involved one meeting which meant two meeting for two cycles. As long the Pre-Lesson Study, we also formulated three student's problems, are low motivation, student's engagement and student's critical thinking. We planned the first learning activities by using Whatsap group. We invited the English teacher to make a Lesson Plan and discuss it in Whatsap group.

To maintain the teacher understands of HOTS and LS, the team provided a workshop which focused on Lesson Study and High Order Thinking Skill (HOTS). It highlighted the history, purpose, and coaching clinic how to implement HOTS in the class through LS In addition, the workshop was held for one day. 12 teachers were participated in this workshop. They were really interested in Lesson Study and HOTS because they were never explained about Lesson Study and HOTS before. They assumed that LS and HOTS are very good for their teaching improvemnet. They believe that LS can provide colaborative learning community which can lead to the betterman of teaching and learning process and the improvement of student's 
achievement in the class. They suggested to create learning community in that school through LS. Moreover, they believe that LS can assist collaborative teaching development for all teachers at that school. However, they assumed that LS is difficult to be implemented because they must work together with other teachers who have different activities and schedule. They must fit their schedule which is not easy to do because of their different workloads. Another problem is affraid to be monitored or critisized by other teachers. They are not accostumed yet to have team teaching.

The preparation for the LS above is very interesting to discuss because the communication mostly used social media as the media to solve the problem related to distance between Indonesia and Thailand which is really far. Leonardi (2017) stated that social can solve the learning barriers including the distance. The researcher equipped email and Whatsaap due to email is one of the most effective media to communicate in the internet (Velasco, Agheneza, Denecke, Kirchner, \& Eckmanns, 2014). Intensive communication can be done in research because of the internet. The internet can provide a new place for teachers to carry out LS without places limitation so that LS can be implemented by involving different countries. In short, the internet can bridge LS among countries and share different experiences. This is very possible to provide good quality education for all.

\section{The Implementation of Lesson Study}

In designing the plan, the LS team focused on the student's engagement and student's critical thingking. These are the basic problems faced by the students at Tarbiah Islamiah School. Most of students assume that learning English is merely supplementary subject which is not needed as mastery than other languages like Arabic language. The background of the school might be one of the causes. This school is Islamic school which really emphasizes on Islamic materials.

\section{Cycle 1}

The first meeting was allocated 120 minutes. The material was daily activities. It was considered as the material because it will be correlated with the student's life. They must know and practice the daily activities expression in real situation. It links with Keshta \& Seif's statement (2013) that one of the HOTS concerns is to associate student's skills with their daily life context. Thus, the materials must be able to assist them to face the real situation when they should interact with their environment. Furthermore, this meeting was sarted by inviting the students to mention the vocabularies related to daily activities, started form they woke up until they sleep again. Most of the students can mention the vocabularies. While the students mentioned the vocabularies, the teacher wrote the vocabularies on the whiteboard, and the teacher invited the students to read loadly the vocabularies. If they made misspronouncitation the teacher corrected them by asking the students to follow his speaking. Then, teacher asked some of the students to pronounciate all words. If the students still made mistakes, the teacher told the correct one. 30 minutes were allotted to this process. Moreover, in this part, the teacher used repeatation and drilling as the technique

The next stage, the teacher remained the language form of daily activities. It involved the tenses and adverb of time and place. Then, the teacher gave the example. After the students understood the language form, the teacher asked the students to make sentences of daily activities. The teacher corrected the student's sentences by inviting the students to follow what the teacher says. In addition, after the students understood with the language form, the students are requested to form a group of 3 students. There 
were seven groups. They were challenged to write 30 words related to daily activities, starting form they wake up until they sleep. Each student had to write 10 words of daily acticities. They should also know the menaing of the words. They enthusiastically discuss with their groupmate. In the other hand, the teachers moved around to supervise the students. 30 minutes were assigned to this activity. In further activity, they should share their works infront of their classmates alternately. The teacher ordered one of the representatives to come forward. The next activitiy is they should explain about adverb of frequency. Most of then could explain it easily because they just mentioned kinds of adverb of frequency, and they also ever learnt in the previous meetings, so they still remembered it. The next activity was writing sentences about daily activities which must use adverb of frequency in every sentence. The teacher asked again the representative of the group to share what they have to other groups. There were some students still made errors with their sentences. The direct feedback was applied in this cycle. The teacher directly gave feedback for the student's performances.

The first cycle run well. Every phase in the plan could be applied. The teacher could perform well, and the students gave good responses to the activities in the class. They could receive the materials; even they could make sentences which are correlated to the materials. Moreover, they enthusisatically join the learning process. Hence, one of the benefit of LS is able to meet the student's need and motivation which can make the students enjoy the class (Sasmini, 2018). It also can perform better engagement (Bjuland \& Mosvold, 2015). They actively participated in every activity. However, there were several concerns in the first cycle. First is to make sure all members in the groups participated. The acticity was not only exposed the representative of the group but it also must be able to cover all students in the class, so all students could practice their English. It was caused by too many groups. If the teacher invited all students to practice, the time would not be anough. Therefore, the next cycle must be able to manage the class well espically in grouping session. Good management class will give impact to time management (Song, Singleton, Hill, \& Koh, 2004). The next problem is speaking exposure. The students had less exprosure in speaking because they focused on learning language form. They tend to memorize the form than they should use it in their daily context. In advance, the teacher focused on repeatation and drilling the languge patterns exposed in daily life activities. The next cycle should be able to trigger the students to expose more their speaking, and the techniques must be able to facilitate the students to polish their speaking. The last challenge is the use of first language (L1) in the class. Many students still used their L1 in the class especially when they had group discussion. L1 use was intensively exposed in group discussion. Moreover, the teacher sometime explained the instruction and the meaning of difficult words by using L1. It made the students was not used to listen and practice their scond language (L2). Therefore, the main concern for the next cycle was to minimize the use of L1 in the class.

The use of L1 in learning is still debatable in learning foreign language. Some experts believe that the use L1 can help students to learn English because it can transfer meaning from L1 to target language. On the other hand, some claim that the use of L1 can make the students longer to speak because they are not used to speak the foregin language. Furthermore, Galali \& Cinkara (2017) stand same position in those debates. They argue that the use of L1 or not to use L1 depends on the situation of the students. 


\section{Cycle 2}

Based on the reflection in the first cycle, the second cycle concerned more on the English exposure than learning English patterns, reducing L1 use in the class, and time management. Therefore, the team designed the learning with various activities which could cope with the weaknesses in cycle one. However, three main plans were formulated. First, the role model would minimize the use of L1 in the class sucha as giving instruction and defining difficult words in English. Second, the activities would focus more on speaking. The students would learn the English pattern along the process. The patterns would be acquired by the students due to they use the language, not memorize the language. LS team recognized that the best startegy to learn language parterns is managing the language as the part of their habbit. The last was formulating better class management.

The material in the second cycle was still daily activities. The teacher opened the class by asking some students their daily activities. After the students could tell their activities, the teachers challenged the students to find errors in sentences spoken by the teacher. This activity aim was to know the student's language form mastery related to asking and giving question someone else daily activities. Considering the student's language form is important to move to the next activity because the next activity is group discussion. They should write 5 questions about daily activities and the answers based on their groupmate's daily activities, so they should interview each other in group to know the other daily activities. However, the teacher moved around to supervise and check whether their questions and answer correct or not. Then, the teacher asked the representative of the group to tell their friend's daily activities. Furthermore, group competition was offered by the teacher to make students more enthusiastic. The groups are given questions about daily activities. The group who can answer correctly more is the winner of the competition. However, the winner got reward by the teacher. Most of students were participated enthusiastically in the competation, and they exposed more their English.

Cycle 2 could answer the challenges appeared in cycle 1, all students were genuinely engaged in learning process. They were really motivated to learn English especially to expose their speaking skill. Most of students are confident to speak. Hence, one of the indication that HOTS is achieved by identifying student's ability to speak. Probowati (2016) stated that HOTS can make students to speak in onder to convey their ideas. The condition in cycle 2 also shown that better improvement could be achieved in cycle 2 because the activities could guide students to use English more for example competation activity which could trigger them to be better than others and they use English. Another approach was the teacher used English more in the class so that students were reluctant to speak L1 in the class although they should confirm difficult words to the teacher. Moreover, the activity did not focus on language form, but to the language use. Students were not afraid again to expose their English.

\section{Conclusion}

In recently years, the motion of HOTS becomes popular in education. It influences almost in all learning aspects in accordance to higher demands to schools to assist their students by good critical thinking which are able to associate with the real situation of students. Thus, HOTS was admitted as one of breakthroughs in learning activities. It was inspired by Bloom's Taxonomy theory which placed creation as a 
needed skill for students. Students are not placed the object of learning anymore, but they must main parts of the learning.

The concepts of HOTS were applied in teaching English through Lesson Study. The implementation of HOTS through Lesson Study can solve the problems faced by students in learning English such students' motivation, low level of critical thinking and the lack of language exposure. Students are more motivated to explore their English by implementing HOTS in the class. Therefore, HOTS can be purposed as one of solution for the teacher to help their students improved.

\section{REFERENCES}

Anderson, T., Howe, C., Soden, R., Halliday, J., \& Low, J. (2001). Peer interaction and the learning of critical thinking skills in further education students. Instructional Science, 29(1), 1-32. https://doi.org/10.1023/A:1026471702353

Bjuland, R., \& Mosvold, R. (2015). Lesson study in teacher education: Learning from a challenging case. Teaching and Teacher Education, 52, 83-90. https://doi.org/10.1016/j.tate.2015.09.005

Dudley, P. (2013). Teacher learning in Lesson Study: What interaction-level discourse analysis revealed about how teachers utilised imagination, tacit knowledge of teaching and fresh evidence of pupils learning, to develop practice knowledge and so enhance their pupils' learning. Teaching and Teacher Education, 34, 107-121. https://doi.org/10.1016/j.tate.2013.04.006

Galali, A., \& Cinkara, E. (2017). The use of L1 in English as a foreign language classes: Insights from Iraqi tertiary level students. Advances in Language and Literary Studies, 8(5), 54. https://doi.org/10.7575/aiac.alls.v.8n.5p.54

Haryoto, S., \& Narimo, S. (2013). Contextual math learning based on Lesson Study can increase study communication. International Journal of Education, 5(4), 48. https://doi.org/10.5296/ije.v5i4.4440

Keshta, A. S., \& Seif, A. (2013). Evaluating the higher order thinking skills in reading of English for Palestine grade eight. Asian Journal of Education and E-Learning, 01(01), 2321-2454. Retrieved from http://library.iugaza.edu.ps/thesis/105688. pdf\%0Awww.ajouronline.com

Kong, S. C. (2015). An experience of a three-year study on the development of critical thinking skills in flipped secondary classrooms with pedagogical and technological support. Computers and Education, 89, 16-31. https://doi.org/10.1016/j.compedu.2015.08.017

Leonardi, P. M. (2017). The social media revolution: Sharing and learning in the age of leaky knowledge. Information and Organization, 27(1), 47-59. https://doi.org/10.1016/j.infoandorg.2017.01.004

Mahanal, S., Zubaidah, S., Bahri, A., \& Dinnurriya, M. S. (2016). Improving students' critical thinking skills through Remap NHT in biology classroom. Asia-Pacific Forum on Science Learning and Teaching, 17(2).

Masyhud. (2018). Lesson study in teaching young learners: Assisting a dynamic classroom interaction. English Education: Jurnal Tadris Bahasa Inggris, 11(1), 93-102.

Mumu, J., \& Tanujaya, B. (2019). Measure reasoning skill of mathematics students. International Journal of Higher Education, 8(6), 85-91. https://doi.org/10.5430/ ijhe.v8n6p85

Nguyễn, T. M. T., \& Nguyễn, T. T. L. (2017). Influence of explicit higher-order thinking skills instruction on students' learning of linguistics. Thinking Skills and 
Creativity, 26, 113-127. https://doi.org/10.1016/j.tsc.2017.10.004

Probowati, Y. (2016). Developing character building model for children based on local wisdom using applications of digital fairy tale. In PROCEEDINGS The 4 th Literary Studies Conference Children's Literature in Southeast Asia. Retrieved from https://www.usd.ac.id/seminar/lsc/wp-content/uploads/2015/06/ProceedingsLSC-2016-Rev.pdf\#page=229

Putra, A. (2018). Best practice " HOTS - home stay "encouraging students ' HOTS through home stay activities. Eltar, 2(1), 13-32.

Sasmini. (2018). Improving student achievement with smart sheets media in Islamic cultural history lesson at the eleventh grade students of MTSN Tarusan. Ilmiah, Journal Scholastic, Pendidikan, 1(154-163).

Setyarini, S., Muslim, A. B., Rukmini, D., Yuliasri, I., \& Mujianto, Y. (2018). Thinking critically while storytelling: Improving children's HOTS and English oral competence. Indonesian Journal of Applied Linguistics, 8(1), 189-197. https://doi.org/10.17509/ijal.v8i1.11480

Song, L., Singleton, E. S., Hill, J. R., \& Koh, M. H. (2004). Improving online learning: Student perceptions of useful and challenging characteristics. Internet and Higher Education, 7(1), 59-70. https://doi.org/10.1016/j.iheduc.2003.11.003

Velasco, E., Agheneza, T., Denecke, K., Kirchner, G., \& Eckmanns, T. (2014). Social media and internet-based data in global systems for public health surveillance: A systematic review. Milbank Quarterly, 92(1), 7-33. https://doi.org/10.1111/14680009.12038

Vermunt, J. D., Vrikki, M., van Halem, N., Warwick, P., \& Mercer, N. (2019). The impact of Lesson Study professional development on the quality of teacher learning. Teaching and Teacher Education, 81, 61-73. https://doi.org/10.1016/ j.tate.2019.02.009

Vrikki, M., Warwick, P., Vermunt, J. D., Mercer, N., \& Van Halem, N. (2017). Teacher learning in the context of Lesson Study: A video-based analysis of teacher discussions. Teaching and Teacher Education, 61, 211-224. https://doi.org/10.1016/j.tate.2016.10.014

Wahono, B., Perdana, E., Study, L., \& Pemula, D. (2013). Peran Lesson Study dalam mensukseskan kurikulum 2013. Seminar Nasional Lesson Study, 70. Jember. 